\title{
ANALYSIS OF INCOME DISTRIBUTION PATTERNS OF BROILER FARMERS IN IMO STATE, NIGERIA
}

\author{
Anyaegbu, C. N., Ibekwe, U. C., Odii, M.A.C.A., Ehirim, N.C. and Chikezie, C. \\ Department of Agricultural Economics, School of Agriculture and Agricultural Technology, \\ Federal University of Technology, Owerri, PMB 1526, Imo State, Nigeria. \\ Corresponding e-mail: casmiranyaegbu@gmail.com
}

\begin{abstract}
This study analyzed the income distribution patterns of broiler farmers in Imo State, Nigeria. The specific objectives were to disaggregate the broiler farmers into different scale of production in the study area; determine the pooled income distribution patterns of broiler farmers in the study area; and to determine the income distribution patterns of broiler farmers across different scale of production. A multi-stage sampling technique was adopted, and a total of 9 LGAs were purposively selected from the 3 zones. Stratified random sampling was used in selecting 26 small-scale, 9 medium-scale and zero large-scale broiler farmers from Owerri Agricultural Zone for the study. In Orlu, 15 small-scale, 15 medium-scale and 6 large-scale of broiler farmers were selected, while 15 small-scale, 11 medium-scale and 3 large-scale broiler farmers were selected from Okigwe Zone using the same method. This gave a total of 113 broiler farmers selected from the chosen LGA's in the state. Out of 113 broiler farmers selected for study only a total of 100 responses were retrieved from the field. The survey was conducted between June 2018 to November 2018. Data were collected on the socio-economic variables of the broiler farmers; scale of operation of broiler farmers; cost of broiler production, imputed cost and income; and revenue from broiler production. Use was made of Gini Coefficient, Lorenz curve, and Decile distribution. The result of this study revealed 3 scale of broiler operation with small-scale having $57 \%$, medium-scale 34\%, while large-scale is 9\%. The study discovered that income was unequally distributed among the broiler farmers and this was confirmed by Gini coefficient value of 0.58 for small-scale broiler farmers, Gini coefficient value of 0.68 for medium-scale farmers, Gini coefficient value of 0.83 for the pooled income of broiler farmers across the state and decile distribution of the pooled income in which $10^{\text {th }}$ decile controls $77.39 \%$ of the total income of broiler farmers while $1^{\text {st }}$ decile controls only $0.52 \%$ of the total income of broiler farmers. The Lorenz curve confirmed the existence of unequal distribution of income which is a deviation from the line of equality. In contrast, income gap among large-scale broiler farmers is very small, thus the distribution pattern can be regarded as relatively equal with a Gini Coefficient value of 0.25. The result reveals that the income gap among broiler farmers in Imo State is too wide to allow broiler farmers to transition from small-scale operation to large-scale which left majority of them as small-scale farmers.
\end{abstract}

Keywords: Income distribution, broiler farmers and scale of operation.

https://dx.doi.org/10.4314/jafs.v17i2.10

Journal of the Faculty of Agriculture and Veterinary Medicine, Imo State University Owerri website: www ajol.info 


\section{INTRODUCTION}

Every economy generates revenue from available natural resource endowments and factors of production. Alexander, Aloni and Ameh (2015) opined that the wealth of a nation depends to a reasonable extent, on her available mineral resources and the level of technological development. The revenue generated from nation resource endowment may vary across the factors of production and or individuals that generated that income. This variation of income across different factors of production is expressed in functional income distribution theory, while the variation of income across individuals is referred to as personal income distribution (Francese \& Mulas-Granados, 2015; Ibekwe, 2001). Personal income distribution pays attention to how income is divided among individuals in a country (Francese \& Mulas-Granados, 2015; Ibekwe, 2001; Pen, 1973) while functional income studies how these factors of production are remunerated (Ibekwe, 2001). The concept of income distribution establishes the basis for richness and poverty since there are differences in the share of income between different people who purchased item from a common market. According to Chikezie et al. (2011) the distribution of a nation's income indicates what proportion of the income goes to the rich and what proportion goes to the poor. It also shows that the rich can purchase many, rather than few goods and services. Hence, the more share a person gets as his/her income, the richer the person. How rich or poor a person also affects his / her purchasing power and consumption pattern.

The manner with which income is equally dealt out among members of a society is described as income distribution. O'Sullivan and Sheffrin (2003) noted that income distribution of a nation is the manner with which the nation's total GDP is distributed amongst its population. Perfect equality of income distribution exists only when everyone's share of national income is exactly the same but perfectly unequal when one person earns all the income within a time period under review. Empirical evidence has suggested that the rapid economic growth of many nations has never translated to economic development due to wide spread inequality in income distribution and high poverty incidence that accompanied the growth process (Oyakhilomen \& Zibah, 2014). The rapid economic growth that occurred between 1965 and 1974 in Nigeria did not translate to economic development because of a serious income disparity that has continued to widen substantially (Matlon, 1979; Aigbokhan, 1999; Ibekwe, 2001). Usually, however, the income distribution of a large population of people in a society is expected to fall somewhere in the middle between equal and unequal earnings. The increasing number of the poor in Nigeria and their average quality of life is a reflection of unequal income distribution. This invariably determines the level of income and standard of living of the people and consequently poor economic development of Nigeria. In most cases, there exist income disparities across industries, professions, and geographical locations, rural and urban areas, which often suggest that higher income share of few group of persons relative to others who purchased from the same market is a policy concern. The differential purchasing power and consumption pattern of individuals are determined by the differences in income share. Therefore, the high incidence of income 
inequality of Nigerian populace draws attention to the level of social, political, economic growth and development issues that calls for a policy change.

Policy interventions of the federal government in the past have not properly addressed this abnormality hence, it persisted. The policy interventions adopted then could not establish economic development although there were tremendous improvements in economic growth (Ibekwe, 2010; Oyekale, Adeoti, \& Ogunnupe, 2004). In normal circumstances, decreasing poverty with closing inequality gap is expected to accompany rapid economic growth but the case of Nigeria is different. Although this is explained in Kuznets paradox (Kuznets, 1946), the effect of economic growth on income inequality and poverty incidences of many nations is not obvious (Babatunde, 2008). Nigeria for instance has continued to record increasing economic growth with income inequality gap rising from 0.429 in 2004 to 0.447 in 2010 as well as a poverty incidences that took an appreciable rise to 69\% in 2010 from $46.3 \%$ in 2004 (Ibekwe, 2010; International Monetary Fund (IMF), 2005; National Bureau of Statistics (NBS), 2010). As if inequality in income distribution is synonymous with poverty, the direct relationship between uneven distributions of income and poverty is very worrisome (McKay, 2002).

Addressing this link is a serious policy challenge to economists and development experts (Adigun \& Awoyemi 2014; Babatunde, 2008). Policies of economic development through economic growth must emphasize on closing income inequality gap with poverty reduction among farmers who are more than $70 \%$ of the population (Babatunde, 2008). The issue of income inequality is seriously fingered in most conflicts amongst ethnic groups, social class and governance. For instance, the unequal distribution of income among farmers show that farm income amongst farming households varies in such a manner that some farmers are rich enough to acquire their required farm input for production while others cannot (Chikezie et al., 2011). The policy of expanded credit access to farmers in Nigeria, which of course came with its own attendant problems, is another dimension to conflict that bedeviled governance. In the same manner are conflicts of interest in chosen professions, where the choice of career interest in farming is low seemingly due to its relatively lower income than other sectors.

Despite the huge natural resource endowment and agricultural potential of most farmers in Nigeria, income distribution gap intertwined with low income incidence has remained a critical developmental challenge. Though low income is prevalent (International Fund for Agricultural Development, (IFAD), (2001)) and Ehirim et al (2017) have described low income as a rural phenomenon in Nigeria and in Imo State in particular. Most empirical evidence suggests that majority of small holder farmers, broiler farmers in particular, belong to low income class who cannot adjust their scale of production (IFAD, 2001; Ehirim et. al., 2012 and Ehirim et al., 2017). This suggest that income gap among broiler farmers in Imo State is too wide to allow broiler farmers to transition from small-scale operation to large-scale which left majority of them as small-scale farmers.

\section{Journal of the Faculty of Agriculture and Veterinary Medicine, Imo State University Owerri} website: www ajol.info 


\section{MATERIALS AND METHOD}

The study was conducted in Imo State which is one of the South Eastern states in Nigeria. The state is made up of twenty-seven (27) local government areas. These local government areas fall into three agricultural established zones; namely, Owerri, Okigwe and Orlu. Owerri agricultural zone is made up of eleven local government areas which include the following: Ezinihitte Mbaise, Ahiazu Mbaise, Aboh Mbaise, Owerri North, Owerri West, Mbaitolu, Ikeduru, Owerri Municipal, Ngor-Okpala, Oguta and Ohaji/Egbema. The Okigwe agricultural zone is made up of six local government areas which include: Obowu, Ihite Uboma, Isiala Mbano, Ehime Mbano, Onuimo and Okigwe. Orlu agricultural zone is made up of ten local government areas which include: Ideato South, Ideato North, Oru East, Oru West, Orsu, Orlu, Isu, Nwangele, Nkwere and Njaba. These divisions are for administrative and extension services and not for any agroecological difference. Imo State was chosen for this study because broiler farming offers a great deal of means of livelihood to a lot of its residents.

The study used a two-stage sampling technique. The three (3) Agricultural Zones; Okigwe, Orlu and Owerri, were used to ensure proper representation of broiler farmers in the state. A list of broiler farmers and their stock sizes in the state from Agricultural Development Programme (ADP) showed that some local government areas do not have any registered broiler farmers. Hence, a purposive selection of three (3) Local Government Areas (LGAs) with large number of registered broiler farmers was done in the first stage. Hereafter, Ezinihitte Mbaise, Oguta and Ikeduru LGAs were selected from Owerri Agricultural Zone, and Nwangele, Orlu and Oru East were selected from Orlu Agricultural Zone, while Okigwe, Isiala Mbano and Obowo LGAs were selected from Okigwe Agricultural zone. The registered LGA's is shown in table 1.0

The second stage was disaggregation of the farmers according to their stock sizes which represent their scale of operation. The categorization into three scale of operations follows Olorunsanya (2004) and Akinkumi, Adegeye, Ikpi, and Olayide (1979) classification scale. A stratified random sampling technique was used to select 113 broiler farmers from across the already selected LGA's in the state. At this stage, 35 broiler farmers were selected from Owerri agricultural Zone while 42 and 36 were selected from Okigwe and Orlu respectively. The stratification was done followed by a proportionate random selection. This is due to the unequal number of broiler farmers in each stratum. In Owerri Agricultural Zone, 26 small-scale, 9 medium-scale and 0 large-scale of broiler farmers were selected for the study. In Orlu, 15 small and medium-scale each and 6 large-scale of broiler farmers were selected. While 15 small-scale, 11 medium-scale and 3 large-scale of broiler farmers were selected from Okigwe Zone.

A well-structured questionnaire was administered to these farmers to elicit information on their operations such as unit prices of input and output quantity of production, revenue, other sources of income and socio-economic characteristics. The study retrieved a total of 100 responses from these farmers. In Owerri Zone, only 35 responses of 26, 9 and 0 from small, medium and largescale farmers were found useful for data analysis. In Orlu, all the 36 questionnaires comprising Journal of the Faculty of Agriculture and Veterinary Medicine, Imo State University Owerri website: www ajol.info 
of 15 each of small and medium-scale and 6 from large-scale broiler farmers were found useful. In Okigwe, only 29 out of 42 responses were found useful for the study. The detail distribution of questionnaire and their retrieved responses are shown in table 1.0.

The study classified broiler farmers into small-scale, medium-scale and large-scale operation following Olorunsanya (2004) and Akinkumi, Adegeye, Ikpi, and Olayide (1979) who sated that a farmer who maintains at least 5000 birds is classified a large-scale producer and farmers with between 500 and 4999 birds are medium-scale producers, while those with less than 500 birds are said to be small-scale producers. Use was also made of Gini Coefficient, Lorenz curve, and Decile distribution to achieve the above-mentioned objectives. To analyze the income distribution patterns of broiler farmers use was made of Gini Coefficient, Lorenz curve, and Decile distribution. The income distribution model is specified below as:

\section{$\mathbf{G}=1-\Sigma X i Y i$}

Where: $\mathrm{G}=$ Gini coefficient

$\mathrm{Xi}=$ proportion of the population

$\mathrm{Yi}=$ cumulative proportion of income

$\Sigma=$ summation sign.

Gini-coefficient is an aggregate inequality measure and can vary from 0 (perfect equality) to 1 (perfect inequality). Perfect equality exists when everyone in the country has equal share of national income, while perfect inequality exists when one person controls the national income and the rest of the individuals hold no income. When the value approaches 0 , it shows that income is equally distributed and it is unequally distributed when the value approaches 1 . It has been noted by Bakare (2012) that Gini coefficient is considered equitable distributions when its value is in the order 0.20 to 0.35 , while it is considered to be unequal income distribution when its value is above 0.35 .

\section{RESULTS AND DISCUSSION}

This section discusses the disaggregation of broiler farmers into different scale of production, the pooled income distribution patterns of broiler farmers and the income distribution patterns of broiler farmers across different scale of production in the study area.

The study classified broiler production into different scale of operations, such as small-scale, medium-scale and large-scale of operations. This is in line with similar studies of Omotosho and Oladele (1988), Subhash et al. (1999), Ojo (2003) and Afolami, Aladejebi, and Okojie, (2013). According to the Table 4.8 shown above, $57 \%$ of the broiler farmers are small-scale, $34 \%$ of them are medium-scale while minority $(9 \%)$ of them are large-scale broiler farmers. Broiler farmers having less than 500 birds were considered as small-scale farmers, above 500 but not up to 5000 birds were categorized as medium-scale farmers while those having 5000 and above

Journal of the Faculty of Agriculture and Veterinary Medicine, Imo State University Owerri website: www ajol.info 
birds were large-scale farmers. This was adjudged by Olorunsanya (2004) and Akinkumi, Adegeye, Ikpi, and Olayide (1979).

\section{Income distribution patterns of broiler farmers in the study area}

In order to ascertain the pattern of income distribution among the broiler farmers in Imo State, the three different scales of operation were pooled together and the result was presented in Table 3.0. Based on the pooled income of the broiler farmers in the study area as presented in Table 3.0 , it is of major concern to note that only $7 \%$ of the population within the income range of $\geq$ $\mathrm{N} 11,500,000$ controls $71 \%$ of the total income of the broiler farmers in Imo State.

While as much $39 \%$ of the pooled population of the broiler farmers within the income range of $\geq$ 500,000 controls only $4 \%$ of the total income in the state. The result reveals the pattern of income distribution that allows the concentration of broiler farmers' income in the hands of the few.

Table 3.0 of pooled income of broiler farmers in the state shows a Gini coefficient value of 0.83 which is very high and close to perfect inequality. Gini coefficient for income distribution shows perfect inequality when the value equals 1 , and perfect equality when the value equals 0 . According to Bakare (2012) and Dillon and Hardaker (1993), Gini coefficient is considered equitable distributions when its value is in the order 0.20 to 0.35 , while it is considered to be unequal income distribution when its value is above 0.35 . The result obtained discloses a disturbing pattern of income distribution among broiler farmers in Imo State. The comparison of the share of total income by each group and the value of Gini coefficient reveal an economic threatening of unequal distribution of income among broiler farmers in Imo State which calls for immediate policy reformation to scale up the production volume of those at the lowest cadre of the distribution to stimulate economic growth.

In addition, the Lorenz curve showed the greatest departure from the $45^{\circ}$ degree line and this corroborates the value of the Gini coefficient of 0.83 which is very unhealthy for economic growth. This implies that the income distribution of broiler farmers in the study area is near perfect inequality which downgrades economic stimulation in Imo State. The income distribution pattern in the study area reveals that many broiler farmers settle at small-scale production. By implication, there is need for external capital injection into broiler production to transition the small and medium producers to large-scale broiler producers.

Table 4.0 shows the decile distribution of pooled income among broiler farmers in the study area to corroborate the results of the Gini coefficient from Table 3.0 and the Lorenz curve in fig 1.0 The decile distribution in Table 4.0 shows the volume of income of 10 broiler farmers in each decile with the corresponding percentage share of the total income of broiler farmers in the state. Each decile consists of 10 broiler farmers with the richest households represented in the 10 decile and the poorest in the 1 st decile. The result reveals that 10 th decile controls $77.39 \%$ of the total pooled income of broiler farmers while 1st decile controls only $0.52 \%$ of the total pooled Journal of the Faculty of Agriculture and Veterinary Medicine, Imo State University Owerri website: www ajol.info 
income of broiler farmers which is not only unhealthy but also discourages economic stimulation among broiler farmers in the state. This is an indication that income distribution among broiler farmers in Imo State is not only unequally distributed but it is unexpectedly near-perfect inequality.

Table 5.0 shows categories of range of income of small-scale broiler farmers with 300,000 to 400,000 housing the highest number of broiler farmers relatively. This range with the highest proportion (0.19) of the small-scale broiler farmers' controls only $13 \%$ of the total income. The poorest resource farmers among small-scale operators fall within the income range of $₫ 00,000$ is made up of $1.8 \%$ of the total respondent controls only but $0.3 \%$ of the total income, while the richest resource farmers among small-scale operators has $7 \%$ of the total respondents fall within an income range of $\geq 1,000,000$ controls $15 \%$ of total income earned per annum. The comparison of the share of total income by each group reveals the unequal distribution of income among small-scale broiler farmers which is worrisome.

Furthermore, the Gini coefficient value of 0.58 reflects the level of unequal distribution of income among small-scale farmers in the study area. Bakare (2012) and Dillon and Hardaker (1993) established a benchmark with Gini coefficient which considered equitable distributions to occur when its value falls anywhere within 0.20 to 0.35 , while it is considered to be unequal income distribution when its value is above 0.35 . Hence, a Gini coefficient value of 0.58 shows that a very high level of inequality in income distribution which is unhealthy for economic growth exist in the study area. The income share disparity among the small-scale broiler farmers in the study area reveals by Gini coefficient of 0.58 shows the pattern of income distribution with a wide gap within the several segments of the small-scale broiler farmers.

The Lorenz Curve (the actual distribution of income curve) is a graphical distribution of income among small-scale broiler farmers in the study area as shown in figure 2.0

Lorenz curve measures the cumulative proportion of income distribution among small-scale broiler farmers on the vertical axis arranged from the poorest to the richest, and the cumulative proportion of the respondents (of small-scale broiler farmers) on the horizontal axis. The diagonal line at the $45^{\circ}$ angle shows perfectly equal income distribution, while the other line (Lorenz curve) shows the actual distribution of income. The further away from the diagonal line (perfect equality), the more unequal the distribution of income. The perfect inequality is a situation in which one person, one broiler farmer in this case, receives total income of broiler framers while everybody else receives nothing. Because no country or industry exhibits either perfect equality or perfect inequality in its distribution of income, the Lorenz curves for different countries and industries will lie somewhere to the right of the diagonal. Based on fig 2.0 above, the Lorenz curve of small-scale broiler farmers is further away from the line of equality which depicts the unequal distribution of income among the small-scale broiler farmers in the study area. This corroborates the Gini coefficient obtained in Table 5.0 that shows a high-income inequality among the small-scale farmers. Table 5.0 reveals Gini coefficient value of 0.58 which 
depicts the pattern of income distribution that allows the concentration of income among smallscale broiler farmers in the hands of the few farmers. The highly unequal income distribution pattern among small-scale broiler farmers in the study reveals that only minute number of the farmers enjoy internal economies of scale at this stage. The theory of economies of scale is expressed as the cost advantages that enterprises obtain by expanding their scale of production with cost per unit of output decreasing with increasing scale. The result implies that only few broiler farmers among small-scale operators can transition to medium-scale if they plough back their income into broiler production.

According to Table 6.0, the highest income earners among medium-scale operators of broiler farming has $12 \%$ of the total respondents which falls within an income range of $\geq 2100000$ controls $47 \%$ of total income per annum followed by $21 \%$ of the respondents with $16 \%$ of the total income at income range of 900000 to 1200000 . While the least income earners control only $1.1 \%$ of total income with an income range of $\leq 300,000$. The comparison of the share of total income by each group reveals the unequal distribution of income among medium-scale broiler farmers which calls for immediate policy reformation to control the situation for economic growth.

In the vein, the Gini coefficient value of 0.68 reflects a pattern of income distribution which indicates a worrisome unequal distribution of income among the medium-scale broiler farmers. Just like in small-scale broiler production, Gini coefficient value of 0.68 portrays the pattern of income distribution that allows the concentration of income in the hands of the few broiler farmers. The situation calls for major concern as the highly unequal income distribution pattern among medium-scale broiler farmers in the study reveals that only minute number of the farmers enjoy internal economies of scale which is unhealthy for economic growth. By implication, only few broiler farmers among medium-scale operators can transition to large scale if they plough back their income into broiler production.

The Lorenz curve in fig 3.0 illustrates the graphical distribution of income level of medium-scale broiler farmers, it also buttresses the fact that the curve tilted widely away from the equality line which is an indication of unequally distribution of income. This supports the Gini-coefficient obtained in Table 6.0 which reveals that the income distribution among the medium-scale broiler farmers concentrate income in the hands of few farmers which favours only a minute population.

More so, the Gini coefficient value of 0.68 among medium-scale broiler farmers in the study area compared with the Gini value of 0.58 of small small-scale broiler farmers confirm that there is a higher income disparity among medium-scale broiler farmers than small-scale broiler farmers. However, capital injection targeting those at the lowest cadre of income distribution is the key to attain even distribution of income among broiler farmers in the study area by extension transition them into large-scale broiler farmers.

The Table 7.0 indicates that there are 9 individual broiler farmers who belong to large-scale producers with their income level ranked in an ascending order. The income level of large-scale Journal of the Faculty of Agriculture and Veterinary Medicine, Imo State University Owerri website: www ajol.info 
broiler operators ranges from $\$ 6,634,800$ to $\$ 78,911,250$ with mean income of $\$ 23,591,389$. The Table 7.0 reveals that $9^{\text {th }}$ individual income share is the highest with $37 \%$ of the total income followed by $8^{\text {th }}$ individual income with $12 \%$ income share. While the $1^{\text {st }}$ individual with the least income share controls only $3.1 \%$ of the total income. It is also noteworthy that only 2 individual farmers $\left(8^{\text {th }}\right.$ and $9^{\text {th }}$ individuals) were above the mean income level while the rest of the 7 individuals received income below the mean income. Though, the entire population of this category enjoys internal economies of scale. The income disparity among the large-scale broiler farmers is bearable.

The Gini coefficient value of large-scale broiler farmers is at the tune of 0.25 which indicates that their income is relatively distributed equally as adjudged by Bakare (2012) who revealed that Gini coefficient that falls between 0.2 and 0.35 is regarded as relatively equitable distribution. It is noteworthy that there is an equality in the income distribution pattern of broiler farmers among large-scale producers in the study area which indicates that all the farmers in this category enjoy internal economies of scale.

The Lorenz curve in figure 4.0 illustrates the graphical distribution of income level of large-scale broiler farmers. It also buttresses the fact that the curve slightly tilted away from the equality line which indicates that the income distribution pattern among large-scale broiler farmers is not perfectly equal. This supports the Gini coefficient obtained in Table 7.0 which reveals that there is a low-income disparity among the large-scale broiler farmers in Imo State. However, attention needs to be given to the broiler farmers at a lower cadre of income distribution through injection to increase number of large-scale broiler farmers in the state in order to stimulate economic growth in the state.

\section{CONCLUSION AND RECOMMENDATION}

From the foregoing analysis it was observed that income was unequally distributed among the broiler farmers which allows the rich to be getting richer and the poor getting poorer on daily basis. This was confirmed by Gini coefficient value of 0.58 for small-scale broiler farmers (table 5.0), Gini coefficient value of 0.68 for medium-scale farmers (table 6.0), Gini coefficient value of 0.83 (table 3.0) for the pooled income of broiler farmers across the state, alongside with decile distribution of the pooled income. The result reveals that the $10^{\text {th }}$ decile controls $77.39 \%$ of the total pooled income of broiler farmers while $1^{\text {st }}$ decile controls only $0.52 \%$ of the total pooled income of broiler farmers. This is by implication, a reflection and peculiarity of the economy among broiler producers in the study area. It is worthy to note that the income is relatively distributed equally among large-scale broiler farmers in the study area with Gini Coefficient value of 0.25 . This was corroborated by Bakare (2012) who revealed that Gini coefficient value that falls between 0.2 and 0.35 is regarded as relatively equitable distribution. Notwithstanding, the result reveals that the income gap among broiler farmers in Imo State is too wide to allow broiler farmers to transition from small-scale operation to large-scale which left majority of them as small-scale farmers. It can be concluded that the wide gap that exist in the income of the 
broiler farmers is not a desirable feature of developing sector. Any sector or industry where the distribution of income is heavily concentrated in the hands of the few is an epitome of underdevelopment and poor economic management. The situation settles many broiler farmers at small-scale production. However, the comparison of the share of total income by each scale of operation reveals an economic threatening of unequal distribution of income among broiler farmers in Imo State which calls for immediate policy reformation to scale up the production volume of those at the lower cadre of income distribution to stimulate economic growth. This can be achieved through capital injection, access and subsidies to production inputs like feed and drugs to small and medium-scale broiler farmers in the state. 


\section{REFERENCES}

Adigun, G. T., \& Awoyemi, T. T. (2014). Economic growth, income redistribution and poverty reduction: Experiences from Rural Nigeria. Asian Journal of Agricultural Extension, Economics \& Sociology, 3(6), 638-653.

Afolami, C. A., Aladejebi, O. J., \& Okojie, L.O. (2013). Analysis of profitability and constraints in poultry egg Farming under battery cage and deep litter systems in Ogun state, Nigeria: a comparative study IJAFS 4(20), 581- 595.

Aigbokhan, B. E. (1999). The impact of adjustment policies and income distribution in Nigeria: An empirical study. Research Report No. 5, development policy centre, Ibadan, Nigeria.

Akinkumi, J. A., Degeye, T. A., Ikpi, A. E., \& Olayode, S. O. (1979). Economic analysis of Nigerian poultry industry. A study commissioned by the Federal Livestock Department, (FLD) Lagos.

Alexander, B. C., Aloni, C., \& Ameh, E. F. (2015). Geographical survey of Nigerian mineral resources: A step toward planned development. An International Peer-reviewed Journal 6, 2422-8400.

Babatunde, R. O. (2008). Income inequality in rural Nigeria: Evidence from farming households survey data. Australian Journal of Basic and Applied Sciences, 2(1), 134-140.

Bakare, A. S. (2012). Measuring the income inequality in Nigeria: the Lorenz curve and Gini coefficient approach. American Journal of Economics 2(1), 47-52 DOI: 10.5923/j.economics.20120201.06

Chikezie, C., Ibekwe, U. C., Ohajianya, D. O., Orebiyi, J. S., Oguoma, N. N., Obasi, P.C., Henri-Ukoha, A., Emenyonu, C.A., Nwaiwu, I. U. (2011). Size distribution of income among rice-based farming households in South Eastern States of Nigeria. International Journal of Agricultural Management \& Development (IJAMAD), 1(1), 31-37.

Dillon, J.L., \& Hardaker, J.B. (1993). Farm management research for small farmer development. Rome: FAO

Ehirim, N.C., Rhaji, M.A.Y., Oguoma, N.N.O., \& Onyeagucha, S.U.O. (2017). Assessment of poverty period of FADAMA 111 participants in Imo State, Nigeria. Asian Journal of Agricultural Extension Economics \& Sociology, 15(4), 1-13.

Francese, M., \& Mulas-Granados, C. (2015). Functional income distribution and its role in explaining Inequality. IMF working paper. Retrieved from https://bit.ly/2JYNOxK

Ibekwe, U.C. (2001). "Income distribution among farm households in Orlu Agricultural Zone of Imo State, Nigeria", Unpublished PH.D, Thesis, University of Nigeria, Nsukka .9-40

Ibekwe, U. C. (2010). Determinants of income among farm households in Orlu Agricultural Zone of Imo State, Nigeria. Report and Opinion, 2(8),32-35. Retrieved from https://bit.ly/2KaPove

International Fund for Agricultural Development (IFAD), (2001). The Challenges of Ending Rural Poverty, Oxford University Press, New York. 250Pp.

Journal of the Faculty of Agriculture and Veterinary Medicine, Imo State University Owerri website: www ajol.info 
International Monetary Fund (IMF). (2005). Nigeria poverty reduction strategy paper. National Economic Empowerment and Development Strategy, IMF Country Report No 05/433.

Kuznets, S. (1946). National product since 1869 (assisted by L. Epstein and E. Zenks), New York: National Bureau of Economic Research.

Matlon, P.J. (1979). Income distribution among farmers in Northern Nigeria: Empirical results and policy implications. African Rural Economy Paper No. 18 Retrieved from https://bit.ly/2Ml7eym

McKay, A. (2002). Defining and measuring inequality. Inequality Briefing Paper No 1. Overseas Development Institute, London, UK.

National Bureau of Statistics, NBS. (2010). Nigerian Poverty Profile Report, January 2010. Abuja: NBS.

Ojo, S. O. (2003). Productivity and Technical Efficiency of Poultry Egg production in Nigeria. Int. J. Poult. Sci. 2,459-464

Olorunsanya, E. O. (2004). Egg Farming Business in Kwara State, How profitable? Agrosearch, $6(1), 9-14$.

Omotosho, O.A., \& Ladele, A.A., (1988). Management problems in large-scale poultry business in Nigeria. Farm Manage. Nig. J., 3: 27-35

O'Sullivan, A., \& Sheffrin, S. M. (2003). Economics: Principles in Action. Upper Saddle River, New Jersey 07458: Pearson Prentice Hall. p. 348. ISBN 0-13-063085-3.

Oyakhilomen, O. \& Zibah, R.G. (2014). Agricultural production and economic growth in Nigeria: Implication for rural poverty alleviation. Quarterly Journal of International Agriculture 53(3), 207-223

Oyekale, A.S., Adeoti, A.I. \& Ogunnupe, T.O. (2004). Sources of income inequality and poverty in rural and urban Nigeria. Paper presented at the 3rd Annual Workshop of Poverty and Economic Policy (PEP) Network Dakar, Senegal, 11th - 20th June 2004.

Subhash, S., Joynal, A. \& Islam, F. (1999). Performance of commercial poultry farms: A profitability and efficiency analysis. Bangladesh J. Agric. Econ., XXII: 63-75

Journal of the Faculty of Agriculture and Veterinary Medicine, Imo State University Owerri website: www ajol.info 


\section{APPENDIXES}

Table 1.0 A breakdown of sample selection of broiler farmers for the study

\begin{tabular}{|c|c|c|c|c|c|c|c|}
\hline \multirow{2}{*}{ Zones } & \multirow{2}{*}{$\begin{array}{l}\text { Number } \\
\text { of } \\
\text { registered } \\
\text { LGA's }\end{array}$} & \multirow{2}{*}{$\begin{array}{l}\text { Number } \\
\text { of } \\
\text { Selected } \\
\text { LGA's }\end{array}$} & \multirow{2}{*}{$\begin{array}{l}\text { Number } \\
\text { of } \\
\text { selected } \\
\text { broiler } \\
\text { farmers }\end{array}$} & \multicolumn{3}{|c|}{$\begin{array}{l}\text { Number of retrieved responses } \\
\text { per scale of operation }\end{array}$} & \multirow{2}{*}{$\begin{array}{l}\text { Total No. } \\
\text { of } \\
\text { responses } \\
\text { retrieved }\end{array}$} \\
\hline & & & & $\begin{array}{l}\text { Small- } \\
\text { scale }\end{array}$ & $\begin{array}{l}\text { Medium- } \\
\text { scale }\end{array}$ & $\begin{array}{l}\text { Large- } \\
\text { scale }\end{array}$ & \\
\hline Owerri & 10 & 3 & 35 & 26 & 9 & 0 & 35 \\
\hline Orlu & 7 & 3 & 36 & 15 & 15 & 6 & 36 \\
\hline Okigwe & 5 & 3 & 42 & 15 & 11 & 3 & 29 \\
\hline Total & 22 & 9 & 113 & 56 & 35 & 9 & 100 \\
\hline
\end{tabular}

Source: Field Survey Data, 2018

Table 2.0 Distribution of broiler farmers according to the scale of operation

\begin{tabular}{llll}
\hline Items & Scale of Operation & Frequency & Percentage \\
\hline Small-scale & $1-499$ & 57 & 57 \\
Medium-scale & $500-4999$ & 34 & 34 \\
Large-scale & 25000 & 9 & 9 \\
Total & & 100 & 100 \\
\hline
\end{tabular}

Source: Field survey data, 2018. 
Volume 17 Number 2, October 2019 pp 116 - 134

Table 3.0 Income distribution of Pooled broiler farmers

\begin{tabular}{|c|c|c|c|c|c|c|c|}
\hline $\begin{array}{l}\text { Income Groupings } \\
(\#)\end{array}$ & $\begin{array}{l}\text { No. of } \\
\text { Broiler } \\
\text { Farmers }\end{array}$ & $\begin{array}{l}\text { Proportion } \\
\text { of Broiler } \\
\text { Farmers Xi }\end{array}$ & $\begin{array}{l}\text { CF Prop } \\
\text { of Broiler } \\
\text { Farmers }\end{array}$ & $\begin{array}{l}\text { Income of } \\
\text { Broiler } \\
\text { Framers }\end{array}$ & $\begin{array}{l}\text { Proportion } \\
\text { of Income }\end{array}$ & $\begin{array}{l}\text { Cum } \\
\text { Proportion } \\
\text { of Pooled } \\
\text { Income Yi }\end{array}$ & XiYi \\
\hline$\leq 500000$ & 39 & 0.39 & 0.39 & $12,295,027$ & 0.044377 & 0.04437709 & 0.017307 \\
\hline $500000-1000000$ & 36 & 0.36 & 0.75 & $26,421,753$ & 0.095365 & 0.13974252 & 0.050307 \\
\hline $1000000-1500000$ & 10 & 0.1 & 0.85 & $11,401,370$ & 0.041152 & 0.18089409 & 0.018089 \\
\hline $1500000-2000000$ & 2 & 0.02 & 0.87 & 3367375 & 0.012154 & 0.19304813 & 0.003861 \\
\hline $2000000-2500000$ & 1 & 0.01 & 0.88 & $2,154,075$ & 0.007775 & 0.20082295 & 0.002008 \\
\hline $4000000-4500000$ & 1 & 0.01 & 0.89 & $4,058,825$ & 0.01465 & 0.21547268 & 0.002155 \\
\hline $5000000-5500000$ & 1 & 0.01 & 0.9 & $5,037,050$ & 0.01818 & 0.23365317 & 0.002337 \\
\hline $6500000-7000000$ & 1 & 0.01 & 0.91 & $6,634,800$ & 0.023947 & 0.25760051 & 0.002576 \\
\hline $9000000-9500000$ & 2 & 0.02 & 0.93 & $9,295,750$ & 0.033552 & 0.29115215 & 0.005823 \\
\hline$\geq 11,500,000$ & 7 & 0.07 & 1 & $196,391,950$ & 0.708848 & 1 & 0.07 \\
\hline Total & 100 & 1 & & $277,057,975$ & 1 & & 0.174463 \\
\hline Gini $=1-\sum X i Y i$ & & & & & & & $\mathbf{0 . 8 2 5 5 3 7}$ \\
\hline
\end{tabular}

Source: Field Survey Data, 2018

Journal of the Faculty of Agriculture and Veterinary Medicine, Imo State University Owerri website: www ajol.info 


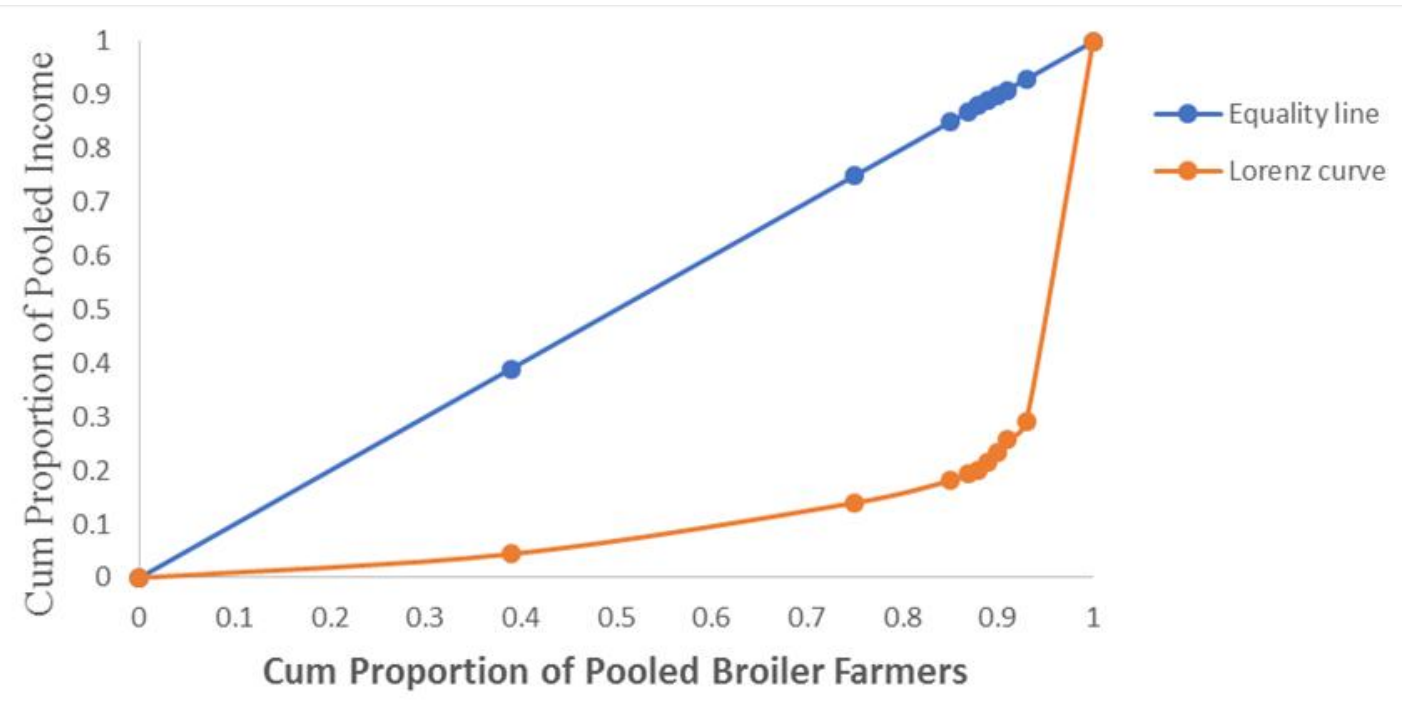

Fig 1.0 Lorenz curve of the pooled broiler farmers in the study area

Table 4.0 Decile distribution of pooled income among broiler farmers in the study area

\begin{tabular}{lll}
\hline Decile & Income N & \% income share \\
\hline 1st Decile & $1,493,513$ & 0.521741 \\
2nd Decile & $2,982,325$ & 1.041839 \\
3rd Decile & $3,764,825$ & 1.315196 \\
4th Decile & $4,566,415$ & 1.595222 \\
5th Decile & $5,474,285$ & 1.912375 \\
6th Decile & $7,162,973$ & 2.502298 \\
7th Decile & $8,436,720$ & 2.947266 \\
8th Decile & $10,099,695$ & 3.528207 \\
9th Decile & $20,754,725$ & 7.250413 \\
10 Decile & $221,520,285$ & 77.38544 \\
\hline
\end{tabular}

Source: Field Survey Data, 2018

Journal of the Faculty of Agriculture and Veterinary Medicine, Imo State University Owerri website: www ajol.info 
Income distribution patterns of broiler farmers across different scale of operations

Table 5.0 Income distribution of small-scale broiler farmers

\begin{tabular}{|c|c|c|c|c|c|c|c|}
\hline Range of income & $\begin{array}{l}\text { No. of } \\
\text { Broiler } \\
\text { Farmers }\end{array}$ & $\begin{array}{l}\text { Prop of } \\
\text { Broiler } \\
\text { Farmers } \\
\text { Xi }\end{array}$ & $\begin{array}{l}\text { CF Prop } \\
\text { of } \\
\text { Broiler } \\
\text { farmers }\end{array}$ & $\begin{array}{l}\text { Income of } \\
\text { Broiler } \\
\text { Framers }\end{array}$ & $\begin{array}{l}\text { Prop of } \\
\text { Income }\end{array}$ & $\begin{array}{l}\text { Cum } \\
\text { Prop of } \\
\text { Income } \\
\text { Yi }\end{array}$ & XiYi \\
\hline$\leq 100000$ & 1 & 0.017544 & 0.017544 & 87,650 & 0.002905 & 0.002905 & $5.097 \mathrm{E}-05$ \\
\hline $100000-200000$ & 2 & 0.035088 & 0.052632 & 271,775 & 0.009009 & 0.011914 & 0.0004180 \\
\hline 200000-300000 & 9 & 0.157895 & 0.210526 & $2,365,863$ & 0.078421 & 0.090335 & 0.0142634 \\
\hline $300000-400000$ & 11 & 0.192982 & 0.403509 & $3,940,750$ & 0.130624 & 0.22096 & 0.0426413 \\
\hline $400000-500000$ & 7 & 0.122807 & 0.526316 & $3,042,990$ & 0.100866 & 0.321826 & 0.0395225 \\
\hline $500000-600000$ & 8 & 0.140351 & 0.666667 & $4,341,813$ & 0.143918 & 0.465745 & 0.0653676 \\
\hline $600000-700000$ & 6 & 0.105263 & 0.77193 & $3,981,888$ & 0.131988 & 0.597733 & 0.0629192 \\
\hline $800000-900000$ & 7 & 0.122807 & 0.894737 & $5,819,505$ & 0.1929 & 0.790632 & 0.0970951 \\
\hline $900000-1,000,000$ & 2 & 0.035088 & 0.929825 & $1,904,750$ & 0.063137 & 0.853769 & 0.0299568 \\
\hline \multirow[t]{2}{*}{$\geq 1,000,000$} & 4 & 0.070175 & 1 & $4,411,570$ & 0.146231 & 1 & 0.0701754 \\
\hline & & & & $30,168,55$ & & & \\
\hline Total & 57 & 1 & & 2 & 1 & & 0.4224106 \\
\hline Gini $=1-\sum X i Y i$ & & & & & & & $\mathbf{0 . 5 7 7 5 8 9 3}$ \\
\hline
\end{tabular}

Source: Field Survey Data, 2018

Journal of the Faculty of Agriculture and Veterinary Medicine, Imo State University Owerri website: www ajol.info 
Volume 17 Number 2, October $2019 p p^{116-134}$

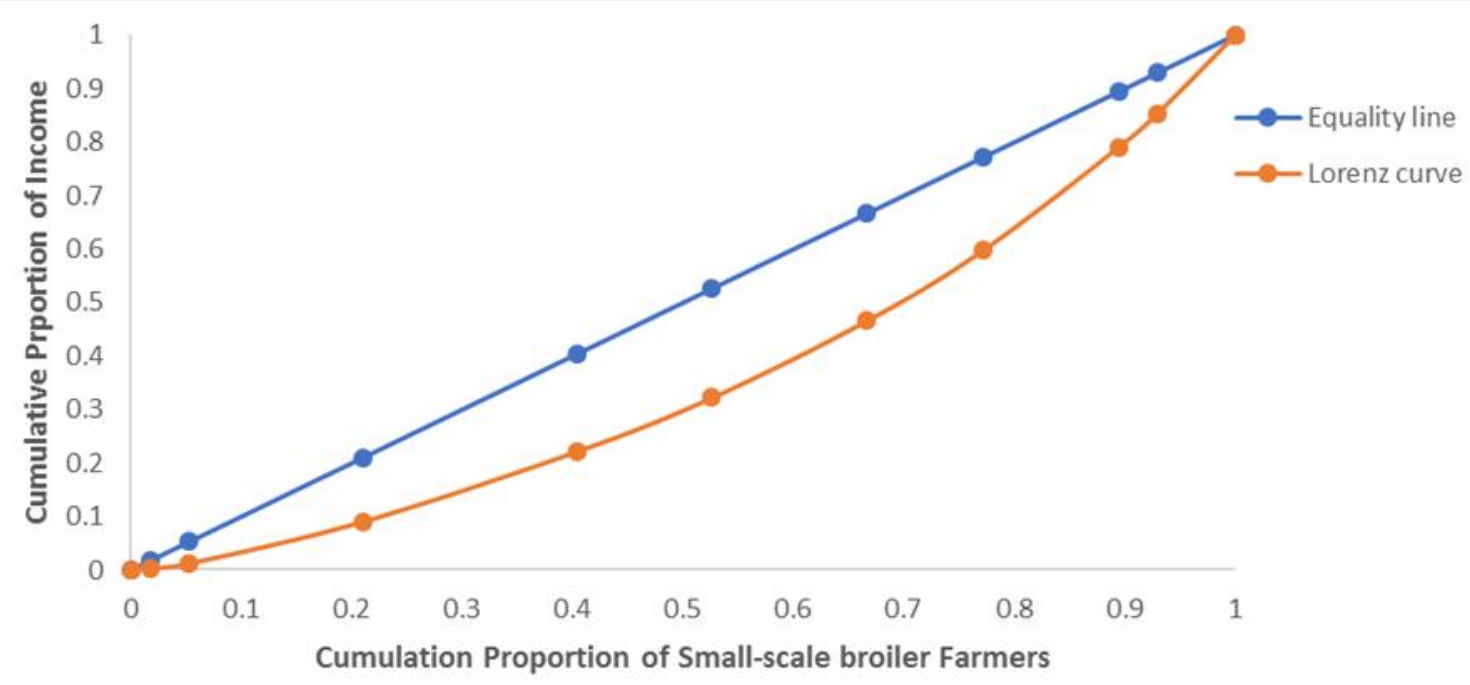

Fig 2.0 Lorenz curve of the small-scale broiler farmers in the study area



Fig 3.0 Lorenz curve of the medium-scale broiler farmers in the study area

Journal of the Faculty of Agriculture and Veterinary Medicine, Imo State University Owerri website: www ajol.info 
Table 6.0 Income distribution pattern of medium-scale broiler farmers

\begin{tabular}{|c|c|c|c|c|c|c|c|}
\hline Range of income & $\begin{array}{l}\text { No. of } \\
\text { Broiler } \\
\text { Farmers }\end{array}$ & $\begin{array}{l}\text { Prop of } \\
\text { Broiler } \\
\text { Farmers } \\
\text { Xi }\end{array}$ & $\begin{array}{l}\text { CF Prop } \\
\text { of } \\
\text { Broiler } \\
\text { farmers }\end{array}$ & $\begin{array}{l}\text { Income of } \\
\text { Broiler } \\
\text { Farmers }\end{array}$ & $\begin{array}{l}\text { Prop of } \\
\text { Income }\end{array}$ & $\begin{array}{l}\text { Cum } \\
\text { Prop of } \\
\text { Income } \\
\text { Yi }\end{array}$ & XiYi \\
\hline$\leq 300000$ & 4 & 0.117647 & 0.117647 & 463,025 & 0.01058 & 0.01058 & 0.001245 \\
\hline $300000-600000$ & 7 & 0.205882 & 0.323529 & $3,162,035$ & 0.072251 & 0.082831 & 0.017053 \\
\hline $600000-900000$ & 7 & 0.205882 & 0.529412 & $5,494,808$ & 0.125553 & 0.208384 & 0.042903 \\
\hline $900000-1200000$ & 7 & 0.205882 & 0.735294 & $6,943,555$ & 0.158656 & 0.367041 & 0.075567 \\
\hline $1200000-1500000$ & 3 & 0.088235 & 0.823529 & $3,886,175$ & 0.088797 & 0.455838 & 0.040221 \\
\hline $1500000-1800000$ & 1 & 0.029412 & 0.852941 & $1,521,825$ & 0.034773 & 0.49061 & 0.01443 \\
\hline $1800000-21000000$ & 1 & 0.029412 & 0.882353 & $1,845,550$ & 0.04217 & 0.53278 & 0.01567 \\
\hline$\geq 2100000$ & 4 & 0.117647 & 1 & $20,447,735$ & 0.46722 & 1 & 0.117647 \\
\hline Total & 34 & 1 & & $43,764,707$ & 1 & & 0.324736 \\
\hline Gini $=1-\sum X \mathbf{X i Y i}$ & & & & & & & 0.675264 \\
\hline
\end{tabular}

Source: Field Survey Data, 2018

CF $=$ Cumulative frequency, Prop $=$ Proportion, Cum $=$ cumulative

Table 7.0 Income distribution of large-scale broiler farmers

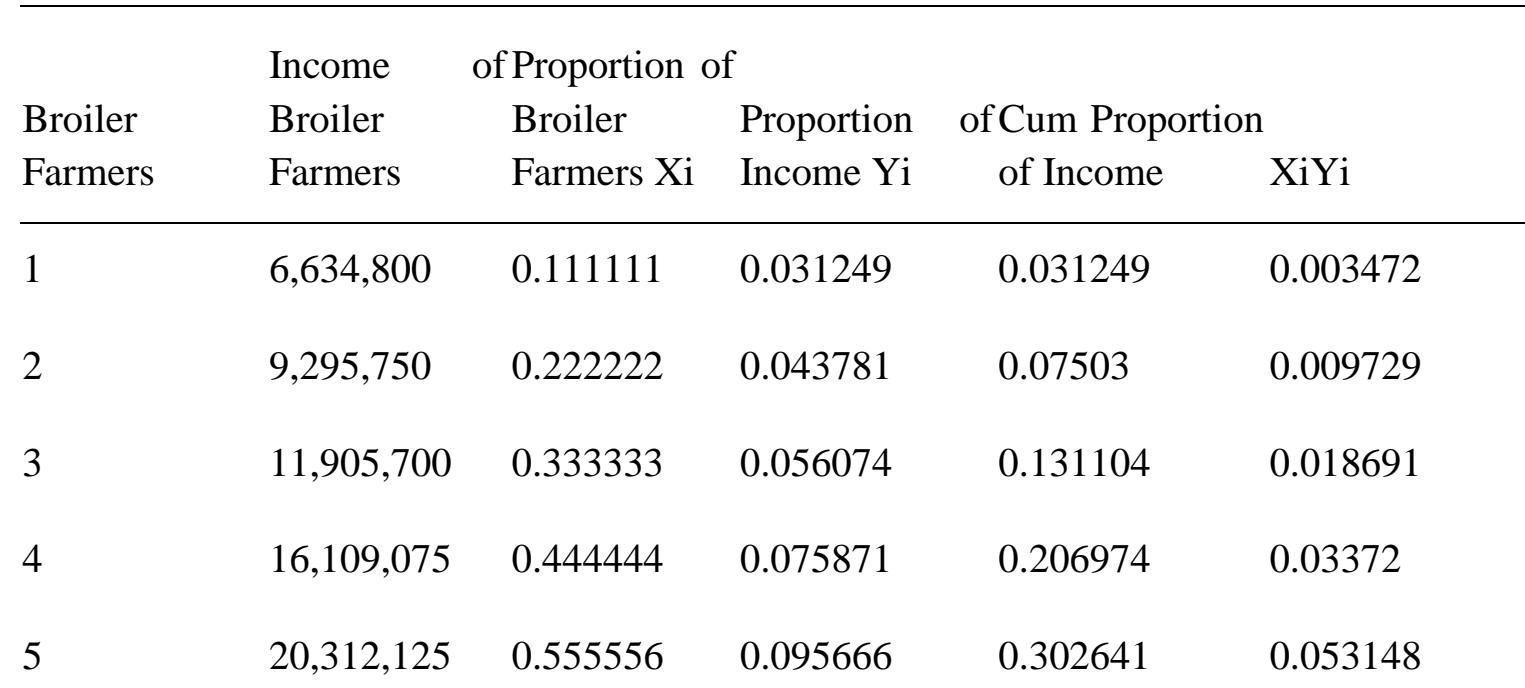

Journal of the Faculty of Agriculture and Veterinary Medicine, Imo State University Owerri website: www ajol.info 


$\begin{array}{llllll}6 & 20,882,400 & 0.666667 & 0.098352 & 0.400993 & 0.065568 \\ 7 & 22,612,600 & 0.777778 & 0.106501 & 0.507494 & 0.082834 \\ 8 & 25,658,800 & 0.888889 & 0.120848 & 0.628342 & 0.107421 \\ 9 & 78,911,250 & 1 & 0.371658 & 1 & 0.371658 \\ \text { Total } & 212,322,500 & & 1 & & 0.746241 \\ \text { Gini }=1-\Sigma \mathrm{XiYi} & & & & & 0.253759\end{array}$

Source: Field Survey Data, 2018

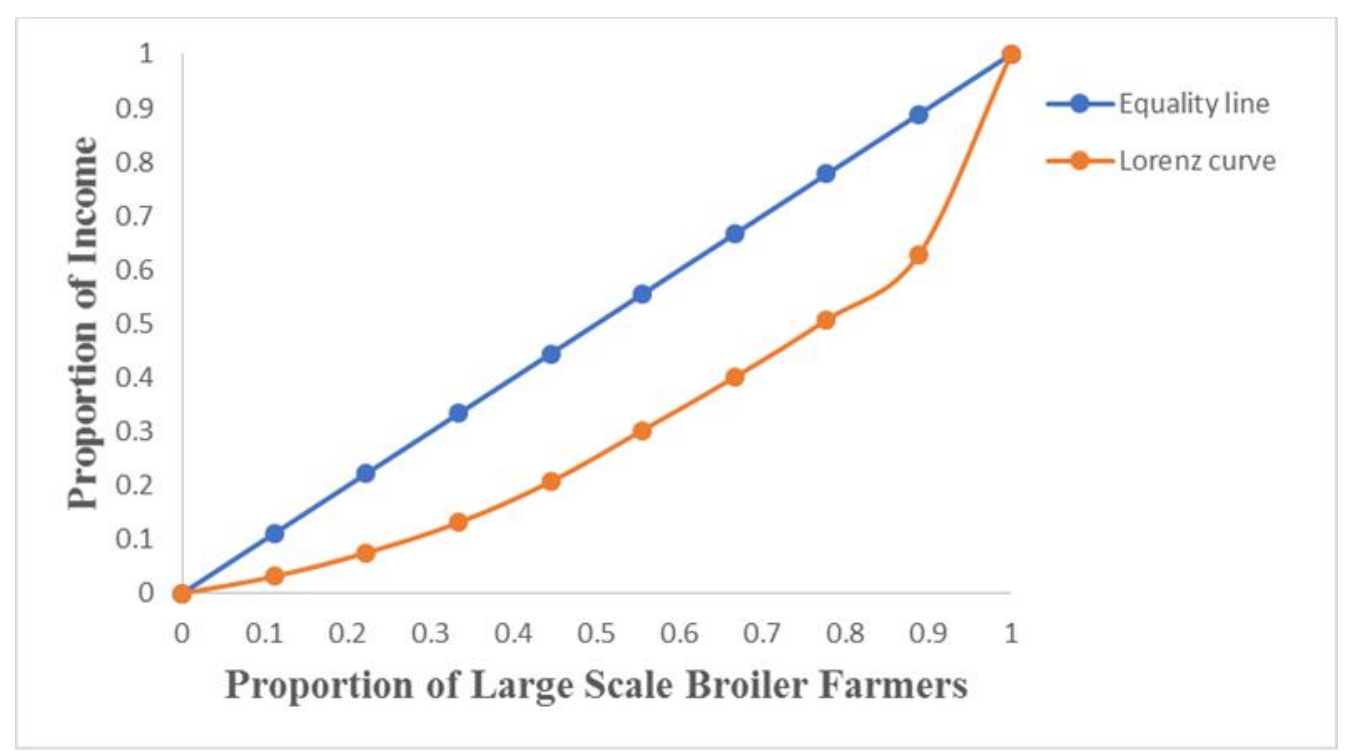

Fig 4.0 Lorenz curve of the large-scale broiler farmers in the study area

Journal of the Faculty of Agriculture and Veterinary Medicine, Imo State University Owerri website: www ajol.info 